[15] HURTAlOVÁ, L., TILlOVÁ, E. (2013). Elimination of the negative effect of Fe-rich intermetallic phases in secondary (recycled) aluminium cast alloy In: Manufacturing Technology, Vol. 13, No. 1, pp. 44-50.

[16] VAŠKO, A. (2013). Influence of heat treatment on the microstructure of synthetic nodular cast iron. In: Manufacturing Technology, Vol. 13, No. 1, pp. 115-119.

Paper number: M201446

Copyright (C) 2014. Published by Manufacturing Technology. All rights reserved.

\title{
Analysis of HVOF Coating on Molds Used for Refractory Fireclay Shapes
}

Libor Beranek, Jiri Kyncl, Petr Mikes

Faculty of Mechanical Engineerign, Czech Technical University in Prague. Technicka 4, 16607, Prage 6. Czech Republic. E-mail: libor.beranek@fs.cvut.cz, jiri.kyncl@fs.cvut.cz,p.mikes@fs.cvut.cz

Molds used for pressing refractory fireclay shapes are exposed to very strong abrasive wear, which is given by the combination of applied pressure of more than $60 \mathrm{MPa}$ and processed materials like alumina $\left(\mathrm{Al}_{2} \mathrm{O}_{3}\right)$ and silica $\left(\mathrm{SiO}_{2}\right)$. Typical lifespan of molds is in several thousand cycles, our aim was to improve the lifespan 10 fold at minimum. To increase the lifespan of the critical parts of the molds, it was decided to use HVOF coating technology based on WC. This article evaluates the quality of the coating on the pins for pressing tools based on the technology used for deposition. An analysis was made on two sets of HVOF coated pins from different suppliers marked as a sample "A and B". Pins were analysed on tactile CMM with scanning system and samples from these pins were analysed on a multisensor CMM.

Keywords: HVOF Coating Thickness, Flatness, Mold Lifespan Increase

\section{References}

[1] NOUROUZI, S., AZIZPOUR, M.J., SALIMIJAZI, H.R., Parametric study of residual stresses in HVOF thermally sprayed WC-12Co Coatings, Materials and Manufacturing Processes, 2014, 29 (9), pp. 1117-1125.

[2] MYALSKA, H., MOSKAL, G., SZYMAŃSKI, K., Microstructure and properties of WC-Co coatings, modified by sub-microcrystalline carbides, obtained by different methods of high velocity spray processes, Surface and Coatings Technology, 2014.

[3] MASOUMI, H., SAFAVI, S.M., SALEHI, M., NAHVI, S.M., Effect of grinding on the residual stress and adhesion strength of HVOF thermally sprayed WC-10Co-4Cr Coating, Materials and Manufacturing Processes, 2014, pp. 1139-1151.

[4] OLADIJO, O.P., VENTER, A.M., CORNISH, L.A., Correlation between residual stress and abrasive wear of WC-17Co coatings, International Journal of Refractory Metals and Hard Materials, 2014, 44, pp. 68-76.

[5] VENTER, A.M., OLADIJO, O.P., LUZIN, V., CORNISH, L.A., SACKS, N., Performance characterization of metallic substrates coated by HVOF WC-Co, Thin Solid Films, 2013, 549, pp. 330-339.

[6] STEWART, D.A., SHIPWAY, P.H., McCARTNEY, D.G., Abrasive Wear Behaviour of Conventional and Nanocomposite HVOF Sprayed WC-Co coatings, Wear, 1999, 225-229, p 789-798

[7] GHABCHI, A., VARIS, T., TURUNEN, E., at al. Behavior of HVOF WC-10Co4Cr Coatings with Different Carbide Size in Fine and Coarse Particle Abrasion, J. Therm. Spray Technol., 2010, 19(1-2), p 368-377

[8] PAWLOWSKI, L.: The Science and Engineering of Thermal Spray Coatings. Second edition. John Wiley \& Sons, Ltd., 2008, 626 p. ISBN 978-0471-49049-4. 